\title{
Vascular patterns in reactive lymphoid tissue and in non-Hodgkin's lymphoma
}

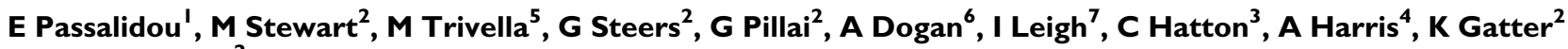 \\ and F Pezzella*,2
}

'3rd Department of Respiratory Medicine, Sismanogleio Hospital, Sismanogleio I, PC 15126 Athens, Greece; ${ }^{2}$ Cancer Research UK Tumour Pathology Group, Nuffield Department of Clinical Laboratory Sciences, John Radcliffe Hospital, Headington, Oxford OX3 9DU, UK; ${ }^{3}$ Department of Haematology, John Radcliffe Hospital, Headington, Oxford OX3 9DU, UK; ${ }^{4}$ Cancer Research UK Medical Oncology Unit, Churchill Hospital, University of Oxford, Oxford; ${ }^{5}$ Cancer Research UK Medical Statistics Group, Centre for Statistics in Medicine, Institute of Health Sciences, Oxford; ${ }^{6}$ Department of Histopathology, University College London, London; 'Centre for Cutaneous Research, Barts and the London, Queen Mary's School of Medicine and Dentistry, London

The few studies published on angiogenesis in lymphoma have raised the question of whether or not microvessel density (MVD) is associated with more aggressive disease and have reported the observation that in follicular lymphomas, vessels are mature rather than immature. We investigated MVD and the vascular phenotype within follicular or diffuse large B-cell lymphomas, reactive nodes and tonsils. Vascular phenotype was defined by the expression or loss of reactivity to the antibody LH39 (detecting the LH39 laminin epitope of the basement membrane in mature vessels) and by detection of $\alpha \vee \beta 3$ (expressed on immature vessels). In reactive nodes and in follicular lymphomas, MVD was higher in the paracortex than in germinal centres or in neoplastic follicles. However, in neoplastic follicles an increase in $\alpha \mathrm{V} \beta 3$-positive endothelium suggested the activation of an angiogenic pathway different from that present in the reactive follicles. In large B-cell lymphomas, MVD was higher than in reactive and neoplastic follicles but lower than in the reactive paracortex. The number of immature vessels ( $\mathrm{LH} 39$ negative) and of $\alpha \mathrm{V} \beta 3$-positive vessels was higher than in reactive lymph nodes and follicular lymphoma suggesting that a switch to a different angiogenic pathway has occurred. Finally, we have demonstrated that within reactive and neoplastic follicles vascular regression is occurring, perhaps constraining the growth of reactive follicles alongside other phenomena such as apoptosis. Vascular regression was previously believed to occur in adults only in ovarian and endometrial tissue. We conclude that different types of angiogenesis are present in follicular lymphomas and large B-cell lymphomas. This has implications for possible future therapies.

British Journal of Cancer (2003) 88, 553-559. doi:I0.1038/sj.bjc.6600742 www.bjcancer.com

(C) 2003 Cancer Research UK

Keywords: lymphoma; lymph node; angiogenesis; vascular regression; vascular phenotype

Evidence supporting a role for neoangiogenesis in haematological malignancies has been found in lymphoid (Perez-Atayde et al, 1997; Kini et al, 1998; Veiga et al, 1998) and myeloid leukaemias (Fiedler et al, 1997; Shami et al, 1998; Pruneri et al, 1999), myeloproliferative disorders, myelodysplasia (Aguayo et al, 1998; Pruneri et al, 1999) and myeloma (Vacca et al, 1994, 1999a; Raza et al, 1999). In non-Hodgkin's lymphomas, expression of angiogenic factors in cell lines (Bellamy et al, 1999) and tissue (Doussis-Anagnostopoulou et al, 1997; Foss et al, 1997; Turley et al, 1998) has been demonstrated.

Although these studies suggest a role for angiogenesis in lymphomas several questions remain unanswered.

First, it is not clear whether high microvessel density (MVD) is associated with more aggressive lymphomas. A group of authors (Ribatti et al, 1996; Vacca et al, 1999b) reported that MVD is higher in lymphomas than in reactive nodes and is higher in

*Correspondence: Dr F Pezzella; E-mail: f.pezzella@cancer.org.uk Received 10 July 2002; revised 14 October 2002; accepted 6 November 2002 aggressive than in indolent lymphomas. However, MVD in reactive nodes has been found to be higher (Ridell and Norrby, 2001) or comparable (Arias and Soares, 2000) to that observed in lymphomas, including large cell lymphomas.

A second intriguing point is the observation by Hyjek et al (Hyjek et al, 1999) that in follicular lymphomas, vessels have mostly a mature phenotype (i.e. have pericytes) rather than an immature as commonly reported in malignancies.

All these authors agree on two points: the neoplastic follicles in follicular lymphoma appear to have fewer vessels than the surrounding paracortex and the high-grade lymphomas. They also noticed that staining for vascular markers highlights a similar vascular distribution in reactive nodes and follicular lymphoma while no reproducible vascular pattern is present in diffuse lymphomas. The authors raised the question as to what this means (Hyjek et al, 1999) but no explanation has yet been proposed.

The present study was aimed at answering these questions by assessing both the MVD and the vascular phenotype of follicular lymphoma, diffuse large B-cell lymphoma (as defined in the WHO classification) (Jaffe et al, 2001) and reactive lymphoid tissues (lymph node and tonsil). We wanted to compare MVD separately 
within the follicles (reactive and neoplastic) and in the paracortex and to match the MVD data with the vascular phenotype. The aim was to provide a more detailed evaluation of pathways of angiogenesis in the neoplastic and physiological conditions, which would be relevant to antivascular therapy strategies.

To distinguish between mature and immature vessels, two markers were investigated. The first marker was the expression of the LH39 epitope interacting with the antibody LH39, which is expressed on the basal membrane of capillaries and small venules in a variety of normal human tissues but is absent in small vessels present in pyogenic granulomas or nonspecific oral ulceration (Almeida et al, 1992a,b). These data have suggested that the detection of LH39 staining discriminates between mature and immature vessels, as supported by four further studies on oral carcinomas (Almeida et al, 1992a), breast carcinomas (Kakolyris et al, 1999) and lung cancer (Kakolyris et al, 1999; Passalidou et al, 2002).

The second marker examined is integrin $\alpha \mathrm{V} \beta 3$ that has been reported to be expressed on newly formed endothelium (Brooks et al, 1994). Many authors have reported, on brain, skin, kidney and lung, that endothelial cells express it to varying degrees (Rabb et al, 1996; Navratil et al, 1997; Pazouki et al, 1997; Passalidou et al, 2002) although in one study of normal human breast tissue the endothelium was negative for $\alpha \mathrm{V} \beta 3$ (Gasparini et al, 1998). While it is well established that endothelial expression of $\alpha \mathrm{V} \beta 3$ is essential for angiogenesis induced by basic fibroblastic growth factor or tumour necrosis factor (Brooks et al, 1994; Friedlander et al, 1995), it has also been found that it can be upregulated in resting endothelium by a variety of biological stimuli (Tang et al, 1994) and that it is also present on resting endothelial cells (Conforti et al, 1992). Study of this integrin remains important as its expression identifies patients who could be eligible for clinical trials with the humanized anti- $\alpha \mathrm{V} \beta 3$ antibody Vitaxin (Gutheil et al, 2000).

\section{MATERIALS AND METHODS}

\section{Tissue samples}

Frozen tissue samples were obtained from the Departments of Histopathology at University College London and at the John Radcliffe Hospital, Oxford. Samples were from 23 patients with follicular non-Hodgkin's lymphoma (of which five had focal transformation to large cell lymphoma), 21 patients with large Bcell non-Hodgkin's lymphoma and 17 with reactive hyperplasia 12 lymph nodes and five tonsils. Fresh tissue was collected in the theatre and frozen in liquid nitrogen. The diagnosis was performed on routine formalin-fixed paraffin-embedded material with the support of appropriate immunostainings according to the WHO classification (Jaffe et al, 2001). One section for each staining was evaluated for each patient for microvessels count. The section contained usually all the lymph nodes.

\section{Immunocytochemistry}

The following antibodies were used: the anti-CD34 monoclonal antibody QB10 (DAKO) staining endothelial cells, the antilamina lucida antigen LH39 antibody and the anti- $\alpha \mathrm{V} \beta 3$ antibody LM609 (Chemicon International, U.K.). Staining for CD3 and CD20 was performed as well. We chose CD34 as endothelial marker as it does not cross-react with lymphoid cells on frozen tissue, as CD31, and stains a wider range of intratumour vessels than anti-Factor VIII antibodies (Vermeulen et al, 1995).

All immunostainings were performed on frozen tissue sections. In the single immunostainings, the primary antibody was incubated for $1 \mathrm{~h}$ at room temperature. Labelling was performed with an avidin-biotin peroxidase system (DAKO Duet). The appropriate secondary antibody was applied for $35 \mathrm{~min}$, after which the Dako streptavidin-biotin complex was applied followed by $\mathrm{DAB}$ solution to develop the staining reaction.

The double immunostaining was performed as follows using the anti-CD34 and anti-LH39 antibodies. Firstly, the anti-LH39 antibody was incubated for $1 \mathrm{~h}$ at room temperature. Labelling was performed with an avidin-biotin peroxidase labelling system (DAKO Duet): the appropriate secondary antibody was applied for $35 \mathrm{~min}$, after which the Dako streptavidin-biotin complex was applied and the staining was developed by applying DAB solution. After rinsing, the sections were incubated overnight with the anti-CD34. After further rinsing sections were incubated with rabbit-anti-mouse immunoglobulins and, finally, with APAAP complexes.

All the cells showing staining were scored as positive, independent of the staining intensity. Staining without the primary antibody was routinely carried out as negative control.

\section{Evaluation of vascularity}

In the present study, microvessel is defined, according to the classic definition of Weidner (1995) as 'capillaries and venules'. We regarded as a distinct countable microvessel any highlighted endothelial cell or cell cluster clearly separated from adjacent microvessels, tumour cells, normal cells and other connective tissue elements according to the international consensus (Vermeulen et al, 1996).

In reactive tissue and in follicular lymphomas, the evaluation of vascularity was performed separately for the follicles (either reactive or neoplastic) and for the paracortical area. In follicular lymphoma cases in which focal large cell lymphoma transformation was present (five cases), the area with a diffuse pattern was scored separately. In diffuse large B-cell lymphomas only the scoring of the neoplastic component was performed.

Evaluation of MVD We counted on each section the five vascular hot spots (i.e. the five areas with the higher number of vessels). Having put the vascular hot-spot area under a high-power field ( $\times 400$ objective), all the vessels present in the field were counted and the value of the sum of the vessels counted in the five spots was calculated.

Evaluation of vascular phenotype To evaluate the proportion of mature vessels, at least 200 vessels were counted from each slide on which double immunostaining for CD34 and LH39 had been performed. If less than 200 vessels were present in the section, they were all counted. The vascular maturation index (VMI) defined by Kakolyris et al (1999) as the percentage of LH39/ CD34-positive vessels to the total of CD34-positive vessels was calculated.

Similarly, an index was derived comparing vessels positive for $\alpha \mathrm{V} \beta 3$ to all the CD34-positive vessels. In this case, the staining was performed on serial sections and the count for CD34 on a section was related to the count for $\alpha \mathrm{V} \beta 3$ on the same areas on the following section. Also in this case, we counted at least 200 CD34positive vessels from each biopsy. If less than 200 vessels were present, they were all counted. In this case, the index indicates the percent of the vessels expressing $\alpha \mathrm{V} \beta 3$.

Evaluation of vascular regression Vessels were scored as regressing according to the criteria described by Holash et al (1999) on rat experimental tumours: briefly, they performed double immunostaining for Smooth Muscle Actin and for Rat Endothelial Cell Antigen. They classified a vessel as regressing when firstly there was endothelial cell detachment followed by endothelial and smooth muscle cell fragmentation. Their criteria were strictly followed (if in any doubt, the vessels were not scored as regressing). The only difference is that instead of looking at 
smooth muscle cells the vascular basal membrane was looked at and identified by the expression of LH39 while we used CD34 as human endothelial marker.

The number of regressing vessels was counted compared with the total number of vessels. All the vessels were scored within the follicles present on each section (either reactive or neoplastic) and the vessels present in five randomly chosen high-power fields in the interfollicular areas (reactive tissue and follicular lymphoma cases) or in the areas of diffuse lymphoma.

\section{Statistical analysis}

Comparisons of MVD counts, number of mature vessels (LH39+) and putative immature vessels $(\alpha \mathrm{V} \beta 3+)$ and comparison of regressing vessels, between follicles and paracortex in reactive hyperplasia and follicular lymphomas, were carried out using paired sample $t$-tests since all vessel values were referring to the same sample. There were 17 reactive samples from nodes and tonsils, and 23 follicular lymphomas. All comparisons gave a significant $P$-value at the $95 \%$ significance level (Tables 1 and 4 ). Independent sample $t$-tests were used for similar comparisons between reactive lymphoid tissue, follicular lymphomas and diffuse large B-cell lymphomas. The $P$-values are given in Tables 2 and 4.

\section{RESULTS}

\section{Microvessel density (MVD)}

Results of MVD scoring are shown in Tables 1 and 2. MVD was lower in the follicles, both reactive (germinal centres) and neoplastic follicles, than in the paracortex (Table 1). There was no difference between the MVD in reactive follicles (germinal centres) and neoplastic follicles or between paracortical areas in reactive tissue and in follicular lymphomas (Table 2). MVD in diffuse large cell lymphomas was higher than MVD in the neoplastic follicles and reactive follicles, but lower than the MVD of the paracortex of reactive lymphoid tissues. MVD instead was similar in diffuse large cell lymphomas and in the paracortex of follicular lymphomas (Table 2).

In five cases of follicular lymphoma, an area of diffuse transformation was present. The average score for MVD in these
Table I Comparison of MVD, number of mature vessels ( $(\mathrm{H} 39+)$ and putative immature vessels $(\alpha \vee \beta 3+)$ between follicles and paracortex in reactive hyperplasia and follicular lymphomas (paired samples $t$-test)

\begin{tabular}{|c|c|c|c|c|}
\hline & Follicles & & Paracortex & $P$-value \\
\hline \multicolumn{5}{|c|}{ Reactive, nodes and tonsils (17) } \\
\hline MVD & 68.7 & vs & 282.5 & $<0.0009$ \\
\hline LH39+vessels & 77.8 & vs & 97.7 & $<0.0009$ \\
\hline$\alpha \vee \beta 3+$ vessels & 10.2 & vs & 22.6 & $=0.044$ \\
\hline \multicolumn{5}{|c|}{ Follicular lymphoma, All (23) } \\
\hline MVD & 65.9 & vs & 184.6 & $<0.0009$ \\
\hline LH39+vessels & 75.8 & vs & 90.4 & $<0.0009$ \\
\hline$\alpha \vee \beta 3+$ vessels & 45.8 & vs & 66.1 & $=0.006$ \\
\hline
\end{tabular}

areas was 110, broadly similar to that observed in the diffuse large B-cell lymphomas. Owing to the small number of cases (only five) no statistical analysis was attempted.

\section{LH39 staining}

In reactive lymphoid tissues the staining with LH39 not only demonstrates the presence of positivity in the basal membrane of vessels and lymphatics, but also highlights an LH39 meshwork present throughout the tissue. Both vessels and lymphatics are within this meshwork. Regression of this meshwork is present in the germinal centres. In lymph nodes the meshwork terminates at the capsule while in tonsil, where the lymphatic tissue is extranodal, no discrete boundaries are present.

In follicular lymphomas the LH39 meshwork is similar to that seen in reactive tissue. As in reactive germinal centres, regression of this meshwork is seen within the neoplastic follicles (Figure 1A, B). The LH39 meshwork is also not present in both large B-cell lymphomas and the focal large cell lymphoma transformations seen in five follicular lymphomas (Figure 1C).

\section{Vascular phenotype}

In Tables 1 and 2, the data concerning the vascular phenotype in reactive lymphoid tissue (tonsil and lymph node) and lymphomas are summarised.

Table 2 Comparison of MVD, number of mature vessels ( $\mathrm{LH} 39+)$ and putative immature vessels $(\alpha \mathrm{V} \beta 3+)$ between reactive lymphoid tissue, follicular lymphomas and diffuse large B-cell lymphomas (independent samples $t$-test)

\begin{tabular}{|c|c|c|c|c|c|c|c|c|}
\hline & $\begin{array}{l}\text { Follicles } \\
\text { reactive }\end{array}$ & & $\begin{array}{c}\text { Follicles follicular } \\
\text { NHL }\end{array}$ & $P$-value & $\begin{array}{l}\text { Paracortex } \\
\text { reactive }\end{array}$ & & $\begin{array}{c}\text { Paracortex } \\
\text { follicular NHL }\end{array}$ & $P$-value \\
\hline $\begin{array}{l}\text { MVD } \\
\text { LH39+vessels } \\
\alpha \vee \beta 3+\text { vessels }\end{array}$ & $\begin{array}{l}68.7 \\
77.8 \\
10.2\end{array}$ & $\begin{array}{l}\text { vs } \\
\text { vs } \\
\text { vs }\end{array}$ & $\begin{array}{l}65.9 \\
75.8 \\
45.8\end{array}$ & $\begin{array}{l}=0.785 \\
=0.689 \\
<0.0009\end{array}$ & $\begin{array}{r}282.5 \\
97.7 \\
22.6\end{array}$ & $\begin{array}{l}\text { vs } \\
\text { vs } \\
\text { vs }\end{array}$ & $\begin{array}{r}184.6 \\
90.4 \\
66.1\end{array}$ & $\begin{array}{l}<0.0009 \\
=0.007 \\
<0.0009\end{array}$ \\
\hline & $\begin{array}{l}\text { Diffuse } \\
\text { B NHL }\end{array}$ & & $\begin{array}{l}\text { Follicles } \\
\text { reactive }\end{array}$ & $P$-value & $\begin{array}{l}\text { Diffuse } \\
\text { B NHL }\end{array}$ & & $\begin{array}{l}\text { Paracortex } \\
\text { reactive }\end{array}$ & $P$-value \\
\hline $\begin{array}{l}\text { MVD } \\
\text { LH39+vessels } \\
\alpha \vee \beta 3+\text { vessels }\end{array}$ & $\begin{array}{r}185.7 \\
50.8 \\
62.7\end{array}$ & $\begin{array}{l}\text { vs } \\
\text { vs } \\
\text { vs }\end{array}$ & $\begin{array}{l}68.7 \\
77.8 \\
10.2\end{array}$ & $\begin{array}{l}<0.0009 \\
=0.007 \\
<0.0009\end{array}$ & $\begin{array}{r}185.7 \\
50.8 \\
62.7\end{array}$ & $\begin{array}{l}\text { vs } \\
\text { vs } \\
\text { vs }\end{array}$ & $\begin{array}{r}282.5 \\
97.7 \\
22.6\end{array}$ & $\begin{array}{l}=0.001 \\
<0.0009 \\
<0.0009\end{array}$ \\
\hline & $\begin{array}{c}\text { Diffuse } \\
\text { NHL }\end{array}$ & & $\begin{array}{c}\text { Follicles } \\
\text { follicular NHL }\end{array}$ & $P$-value & $\begin{array}{l}\text { Diffuse } \\
\text { B NHL }\end{array}$ & & $\begin{array}{c}\text { Paracortex } \\
\text { follicular NHL }\end{array}$ & $P$-value \\
\hline
\end{tabular}



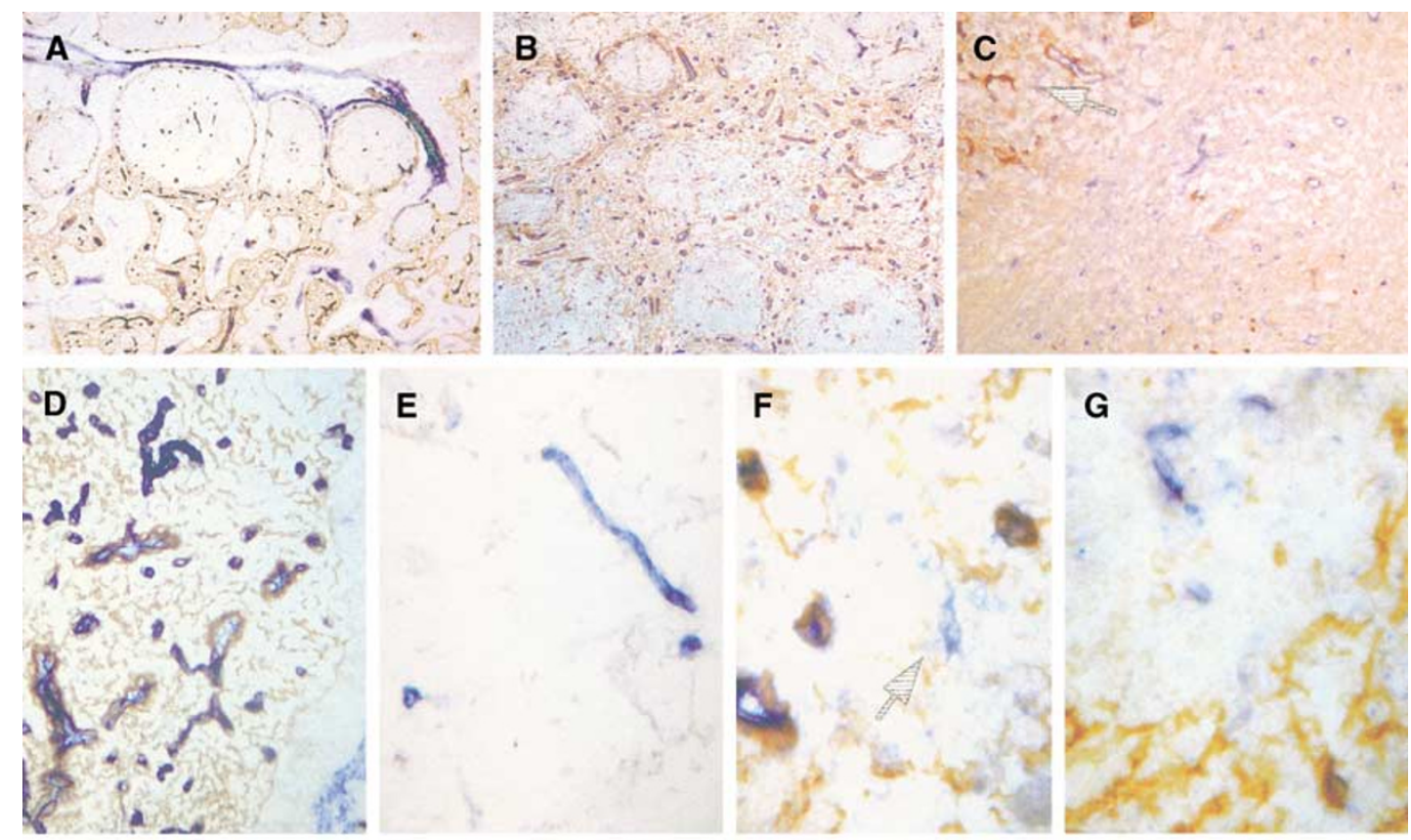

E
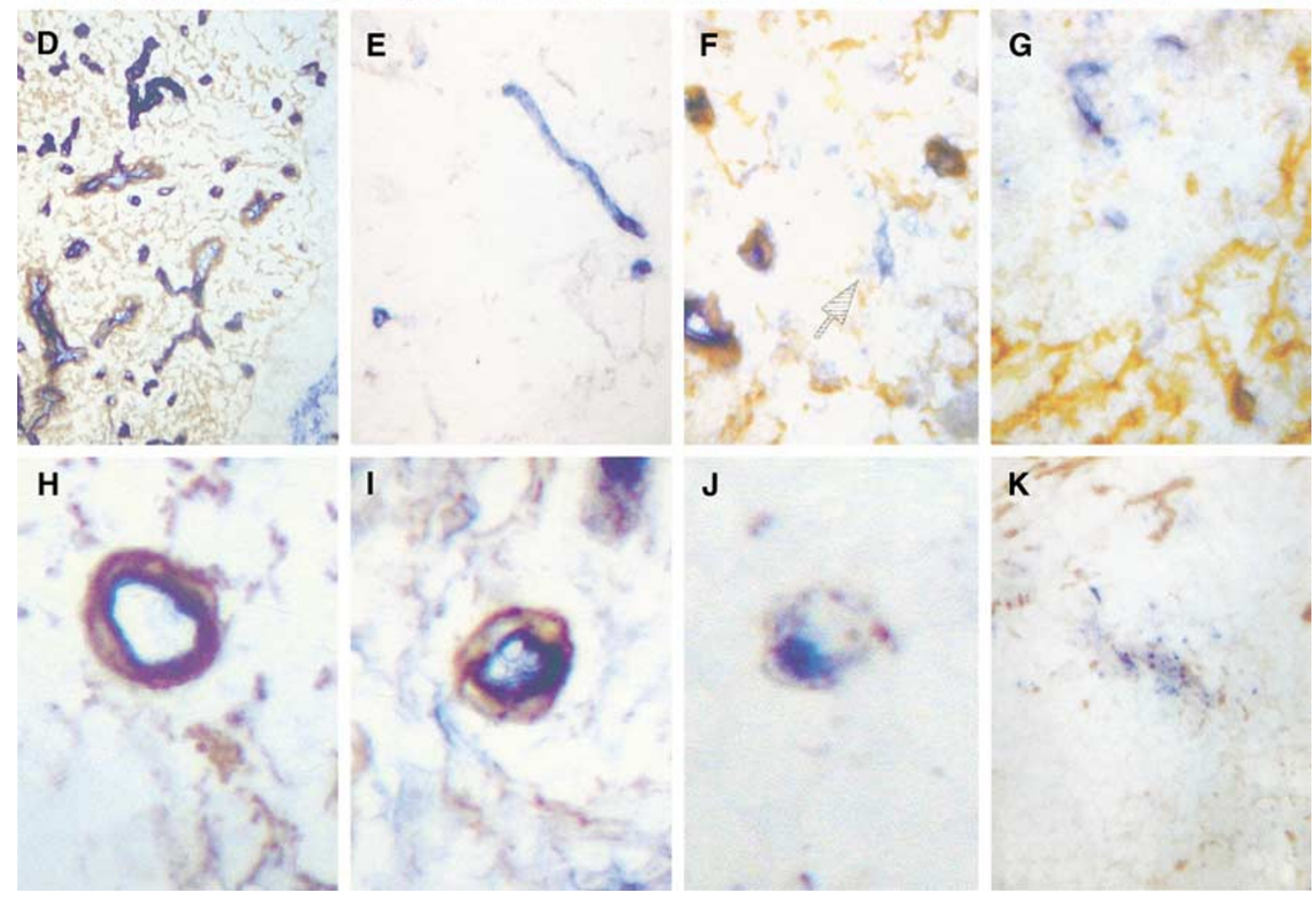

J
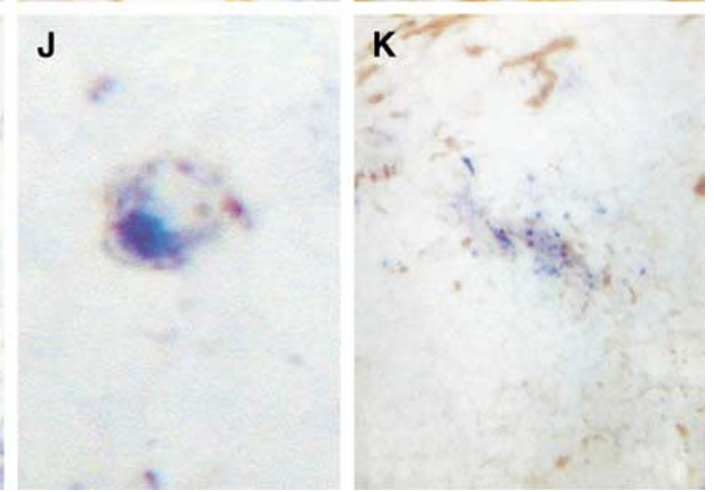

Figure I Vascular phenotype in reactive and neoplastic lymph nodes. LH39-positive meshwork in $(\mathbf{A})$ a reactive lymph node (B) a follicular lymphoma and $(\mathbf{C})$ a large B-cell lymphoma; in the latter only a few residual fragments of the LH39 meshwork are present (arrow). (D) Reactive lymph nodes: all the vessels in the paracortex are within the LH39 meshwork while (E) LH39-negative vessels are present within a germinal centre. (F) Only rare LH39-negative vessels are seen in the paracortex in Follicular lymphomas (arrow) while $(\mathbf{G})$ some more are present in the neoplastic follicles (arrows). Sequence of vascular regression: $(\mathbf{H})$ A normal vessel in which the endothelial cells and the LH39-positive basal membrane are superimposed. (I) early detachment of the endothelial cells from the basal membrane. (J,K) Progressive fragmentation of both endothelial cells and basal membrane leading to vascular regression.

In the paracortex of the reactive lymph nodes, all the vessels were LH39 positive and were associated with the LH39 meshwork (Figure 1D): LH39-negative vessels could not be detected. In reactive tonsils some LH39-negative vessels were present on the edge of the lymphoid tissue and they accounted for $7.8 \%$ of the paracortical vessels. The paracortex of follicular lymphoma nodes differed from the paracortex of reactive nodes as some LH39negative vessels were seen in the former (Figure $1 \mathrm{~F}$ ). Also, the number of $\alpha \mathrm{V} \beta 3$-positive vessels was different as less $\alpha \mathrm{V} \beta 3$ positive vessels were seen in the paracortex of the reactive tissue (Table 2).

Reactive follicles contained instead some LH39-negative vessels (Figure 1E) and the same results were found in neoplastic follicles (Figure 1G). Both in reactive and neoplastic follicles the proportion of mature LH39-positive vessels was the same (Table 2). However, the number of vessels positive for $\alpha \mathrm{V} \beta 3$ was lower in reactive than in neoplastic follicles.

The proportion of LH39-positive vessels within the large cell lymphomas was lower than that observed in reactive tissue and follicular lymphoma (both in follicles and paracortex). The number of $\alpha \mathrm{V} \beta 3$ vessels was instead comparable to that seen in follicular lymphomas (follicles and paracortex) and was higher than the number of $\alpha \mathrm{V} \beta 3$-positive vessels seen in reactive tissue (follicles and paracortex) (Table 2).

\section{Vascular regression}

Results of the scoring for vascular regression are shown in Tables 3 and 4. Examples of the vessels scored as regressing are shown in Figure $1 \mathrm{H}-\mathrm{K}$. The percentage of regressing vessels was higher in follicles (reactive and neoplastic) than in the paracortex (Table 3 ). Table 4 shows that the same high proportion of regressing vessels was present in reactive and neoplastic germinal centres, while only occasional regressing vessels were present, in a similar fashion, in large cell lymphomas and in paracortical areas.

\section{DISCUSSION}

The discrepancies in previous studies (Veiga et al, 1998; Hyjek et al, 1999; Ribatti et al, 1999; Vacca et al, 1999b; Arias and Soares, 2000; Ridell and Norrby, 2001) concerning MVD values in reactive 
Table 3 Comparison of percentage of regressing vessels between follicles and paracortex in reactive hyperplasia and follicular lymphomas (paired samples t-test)

\begin{tabular}{lcccc}
\hline & $\begin{array}{c}\text { Follicles \% } \\
\text { regressing } \\
\text { vessels }\end{array}$ & $\begin{array}{c}\text { Paracortex \% } \\
\text { regressing } \\
\text { vessels }\end{array}$ & P-value \\
\hline Reactive, nodes only (II) & 9.0 & vs & 0.2 & $=0.021$ \\
Reactive, nodes and tonsils (16) & 10.4 & vs & $2.1^{\text {a }}$ & $=0.010$ \\
Follicular NHL all (2I) & 10.1 & vs & 0.2 & $<0.0009$
\end{tabular}

The high value reported in the paracortex of reactive tonsils is because of a single case of reactive tonsil in which $24 \%$ of the paracortical vessels showed signs of regression.

lymphoid tissues and lymphomas were the primary issue for this investigation. Our data confirm that both in reactive lymph nodes and in lymph nodes with follicular lymphomas, the MVD is higher in the paracortex than in the follicles and that there is no difference in MVD between reactive germinal centres and neoplastic follicles. Finally, it was shown that MVD in the paracortex in reactive nodes is higher than in the paracortex of follicular lymphomas and is also higher than in diffuse large cell lymphomas. This is of interest because of the general consensus that angiogenesis is higher in cancer than in non-neoplastic tissues. However, it is reasonable to think that in the reactive nodes physiologic angiogenesis is more effective than the tumour-induced one.

Therefore, we did not confirm the data suggesting that MVD in lymphomas is higher than in reactive lymphoid tissue (Ribatti et al, 1996; Vacca et al, 1999b).

The follicular component of follicular lymphomas has an MVD lower than large B-cell lymphomas. However, a number of neoplastic cells in follicular lymphomas are also present in the paracortex where the MVD is comparable to that of large cell lymphomas, suggesting that MVD alone is unlikely to be dictating the aggressiveness of the lymphoma. This finding also suggests that the neoplastic cells colonizing the paracortex might exploit the existing vessels in the same way that we and others (Miliaras et al, 1995; Guidi et al, 2000; Pezzella et al, 2000; Naresh et al, 2001) have suggested for solid tumors in reactive nodes.

Our study also revealed a previously unknown anatomical characteristic of the lymph node, that is, an extracellular meshwork identified by the expression of LH39. Within this meshwork, in reactive node, are contained all the vessels. When a reactive germinal centre develops, lysis of this meshwork and vascular regression occurs. This meshwork is also present in extranodal lymphatic tissue, that is, tonsil. As this organ has no discrete boundaries (i.e. a capsule) newly formed LH39 vessels are observed at the edge, probably recruited from the surrounding stroma.

The observation of vascular regression in the germinal centre, associated with neoangiogenesis is the second novel finding. Active vascular remodelling and angiogenesis in adult normal tissues were until now thought to be limited to endometrium, ovary and breast, under the control of cyclic hormonal changes (Augustin, 2000). The occurrence of physiological vascular regression and neoangiogenesis in germinal centres makes it a valuable place to study the pathways regulating normal vascular remodelling (e.g. the angiopoietin pathway) (Holash et al, 1999). Furthermore, it also suggests that this could be one of the mechanisms of growth control that alongside others, like the lack of bcl-2, limits the expansion of germinal centre cells. It needs also to be clarified how the vascular regression is regulated and whether apoptosis plays a role in it.

This situation described in reactive nodes is maintained in follicular lymphomas as summarised from the literature (Stewart et al, 2002) (Doussis-Anagnostopoulou et al, 1997) in Table 5 with only three differences: a higher expression of $\alpha \mathrm{V} \beta 3$, the presence in the paracortex of a few immature (LH39-negative) vessels and the expression of VEGF on the neoplastic cells. The observations by Hyjek et al (1999) that mostly mature vessels are present in follicular lymphomas and that the same overall vascular distribution is seen in follicular lymphoma and reactive nodes could be explained by the fact that a similar angiogenic pathway might be activated in both of these conditions. However, our data showing a difference, small but significant, in LH39-negative and $\alpha \mathrm{V} \beta 3$ positive vessels suggest that in the paracortex of follicular lymphomas a second angiogenic pathway is appearing.

A different situation is found in large B-cell lymphomas: regression of the LH39 meshwork occurs while only occasional regressing vessels are seen. This finding supports the hypothesis that in follicular lymphoma the neoplastic cells retain the ability to balance neoangiogenesis with vascular regression. This characteristic is lost in large cell lymphoma and could be another factor contributing to their aggressiveness.

Secondly, although large cell lymphomas have a lower MVD than the reactive paracortex, the phenotype of the vessels is different. Half of them are immature (LH39-negative) and $\alpha \mathrm{V} \beta 3$ is widely expressed. These data indicate that the angiogenic pathway producing immature vessels becomes predominant during the progression from follicular to diffuse lymphoma. Furthermore, the balance between neoangiogenesis and vascular regression, still maintained in neoplastic follicles, is lost in diffuse large cell lymphomas. Large B-cell lymphomas therefore have a vascular

Table 4 Comparison of percentage of regressing vessels between reactive lymphoid tissue, follicular lymphomas and diffuse large B-cell lymphomas (independent samples t-test)

\begin{tabular}{|c|c|c|c|c|c|c|c|c|}
\hline & $\begin{array}{l}\text { Follicles } \\
\text { reactive }\end{array}$ & & $\begin{array}{c}\text { Follicles } \\
\text { follicular NHL }\end{array}$ & $P$-value & $\begin{array}{c}\text { Paracortex } \\
\text { reactive }\end{array}$ & & $\begin{array}{c}\text { Paracortex } \\
\text { follicular NHL }\end{array}$ & $P$-value \\
\hline \multirow[t]{2}{*}{ Regressing vessels (\%) } & 10.4 & vs & 10.1 & $=0.940$ & 2.1 & vs & 0.2 & $=0.223$ \\
\hline & $\begin{array}{l}\text { Diffuse } \\
\text { NHL }\end{array}$ & & $\begin{array}{l}\text { Follicles } \\
\text { reactive }\end{array}$ & $P$-value & $\begin{array}{l}\text { Paracortex } \\
\text { reactive }\end{array}$ & & $\begin{array}{l}\text { Diffuse } \\
\text { B NHL }\end{array}$ & $P$-value B \\
\hline & $\begin{array}{l}\text { Diffuse } \\
\text { NHL }\end{array}$ & & $\begin{array}{c}\text { Follicles } \\
\text { follicular NHL }\end{array}$ & $P$-value & $\begin{array}{l}\text { Diffuse } \\
\text { B NHL }\end{array}$ & & $\begin{array}{l}\text { Paracortex } \\
\text { follicular NHL }\end{array}$ & $P$-value \\
\hline Regressing vessels (\%) & 0.4 & vs & 10.1 & $<0.0009$ & 0.4 & vs & 0.2 & $=0.469$ \\
\hline
\end{tabular}


Table 5 Summary of angiogenesis-related features in lymph nodes (data from the present paper, Stewart et al (2002) and Doussis-Anagnostopoulou et al $(1997))$

(A) Reactive germinal centres, neoplastic follicles and diffuse large cell NHL

\begin{tabular}{|c|c|c|c|}
\hline NHL & Reactive germinal centres & Neoplastic follicles & Diffuse large B cell \\
\hline MVD & 69.7 & 63 & 185 \\
\hline Mature LH39\%+ & $79.6 \%$ & $76.5 \%$ & $\mathbf{5 0} \%$ \\
\hline LH39 meshwork & Lysis & Lysis & Lysis \\
\hline$\alpha \vee \beta 3+$ & $6.3 \%$ & $43 \%$ & $62.7 \%$ \\
\hline Regressing vessels & $9 \%$ & $10.6 \%$ & $0.4 \%$ \\
\hline Hifla & $+21 / 25(84 \%)$ & $+17 / 30(56 \%)$ & $37 / 48(77 \%)$ \\
\hline $\mathrm{Hif2a}$ & $\mathrm{Mac}$ & $\mathrm{Mac}$ & $\mathrm{Mac}++$ \\
\hline CA IX nuclear & Mac (several) & Mac (several) & Mac (few) \\
\hline CA IX membrane & Absent & Absent & 7 out of 48 (15\%) \\
\hline VEGF & Mac & Neoplastic cells & Neoplastic cells \\
\hline TP cells & Mac/FDR & $\mathrm{Mac} / \mathrm{FDR}$ & Dendritic like cells \\
\hline
\end{tabular}

(B) Paracortex from reactive lymph nodes, paracortex in lymph nodes with follicular lymphoma and diffuse large cell NHL

\begin{tabular}{llll}
\hline NHL & Reactive LN paracortex & FL lymph node paracortex & Diffuse large B cell \\
\hline MVD & 287 & $\mathbf{1 8 0}$ & $\mathbf{1 8 5}$ \\
Mature LH39\%+ & $100 \%$ & $\mathbf{9 0 . 9 5 \%}$ & $\mathbf{5 0 \%}$ \\
LH39 meshwork & Present & Present & $\mathbf{L y s i s}$ \\
$\alpha$ V $33+$ & $20.7 \%$ & $\mathbf{6 6 \%}$ & $\mathbf{6 2 . 7 \%}$ \\
Regressing vessels & $0.2 \%$ & $0.2 \%$ & $0.4 \%$ \\
Hifla & Rare & Rare & 37 out of 48 cases $(77 \%)$ \\
Hif2a & Several & Several & mac++ \\
CA IX nuclear & Absent & Absent & Mac (few) \\
CA IX membrane & Absent & Absent & $\mathbf{7}$ out of 48 cases (15\%) \\
VEGF & Mac few & Neoplastic cells & Neoplastic cells \\
TP & Mac/IDR & Mac/IDR & Dendritic-like \\
\hline
\end{tabular}

phenotype comparable to that observed in solid tumours (Kakolyris et al, 1999, 2000; Passalidou et al, 2002).

Lymphatic vessels have not been investigated in this study. Efforts have been made to exclude them on morphological examination but the recent identification of the molecule Lyve 1 and the raising of a specific antibody against this protein (Skobe et al, 2001), which is specifically expressed on lymphatic vessels, will allow this to be properly investigated in normal and neoplastic lymph nodes in future studies.

The heterogeneous patterns of vascularity observed in this study suggest that different types of approach may be needed to exploit anti-angiogenic treatment in lymphomas. In follicular lymphomas, where vessels are mostly mature but with $\alpha \mathrm{V} \beta 3$ expression, the humanised anti- $\alpha \mathrm{V} \beta 3$ antibody Vitaxin (Gutheil et al, 2000) might be suitable. In contrast, antiangiogenic drugs interacting with the formation of new vessels may be more effective in diffuse large Bcell lymphomas.

\section{REFERENCES}

Aguayo A, Kantariian H, Talpaz M, Estey E, Koller C, Estrov Z, O’Brien S, Keating M, Barlogie B, Albitar M (1998) Increased angiogenesis in chronic myeloid leukaemia and myelodisplastic syndromes. Blood 92: 607a

Almeida BM, Challacombe SJ, Eveson JW, Morgan PR, Purkis PE, Leigh IM (1992a) The distribution of LH39 basement membrane epitope in the tumour stroma of oral squamous cell carcinomas. J Pathol 166: 369-374

Almeida BM, Challacombe SJ, Eveson JW, Smith CG, Leigh IM (1992b) A novel lamina lucida component of epithelial and endothelial basement membranes detected by LH39 monoclonal antibody. J Pathol 166: $243-253$

Arias V, Soares FA (2000) Vascular density (tumor angiogenesis) in nonHodgkin's lymphomas and florid follicular hyperplasia: a morphometric study. Leuk Lymphoma 40: 157-166
In conclusion, our data support the hypothesis that follicular lymphomas grow in a fashion very similar to that of reactive lymph nodes while large B-cell lymphomas have angiogenic patterns similar to that seen in many epithelial tumors.

\section{ACKNOWLEDGEMENTS}

We thank Dr Kingsley Micklem, Medical Informatics Unit, University Department of Cellular Science, Oxford, for his help in editing the artwork and Mrs Sue Pinson, Cancer Research UK, for assistance in the preparation of the manuscript. This study was supported by Cancer Research UK and by 'The Special Trustees of the Middlesex Hospital, University College Hospital and University College London Medical School'. EP was supported by a Research Fellowship from the European Respiratory Society.
Augustin HG (2000) Vascular morphogenesis in the ovary. Baillieres Best Pract Res Clin Obstet Gynaecol 14: 867-882

Bellamy WT, Richter L, Frutiger Y, Grogan TM (1999) Expression of vascular endothelial growth factor and its receptors in hematopoietic malignancies. Cancer Res 59: 728-733

Brooks PC, Clark RA, Cheresh DA (1994) Requirement of vascular integrin alpha v beta 3 for angiogenesis. Science 264: 569-571

Conforti G, Dominguez-Jimenez C, Zanetti A, Gimbrone Jr MA, Cremona O, Marchisio PC, Dejana E (1992) Human endothelial cells express integrin receptors on the luminal aspect of their membrane. Blood 80: 437-446

Doussis-Anagnostopoulou IA, Remadi S, Turley H, Gindre P, Comley M, Borisch B, Gatter KC (1997) Platelet-derived endothelial cell growth 
factor/thymidine phosphorylase immunohistochemical expression in lymphoid tissue and lymphoid malignancies. Hum Pathol 28: $1146-1151$

Fiedler W, Graeven U, Ergun S, Verago S, Kilic N, Stockschlader M, Hossfeld DK (1997) Vascular endothelial growth factor, a possible paracrine growth factor in human acute myeloid leukemia. Blood 89: $1870-1875$

Foss HD, Araujo I, Demel G, Klotzbach H, Hummel M, Stein H (1997) Expression of vascular endothelial growth factor in lymphomas and Castleman's disease. J Pathol 183: 44-50

Friedlander M, Brooks PC, Shaffer RW, Kincaid CM, Varner JA, Cheresh DA (1995) Definition of two angiogenic pathways by distinct alpha v integrins. Science 270: $1500-1502$

Gasparini G, Brooks PC, Biganzoli E, Vermeulen PB, Bonoldi E, Dirix LY, Ranieri G, Miceli R, Cheresh DA (1998) Vascular integrin alpha(v)beta3: a new prognostic indicator in breast cancer. Clin Cancer Res 4: $2625-2634$

Guidi AJ, Berry DA, Broadwater G, Perloff M, Norton L, Barcos MP, Hayes DF (2000) Association of angiogenesis in lymph node metastases with outcome of breast cancer. J Natl Cancer Inst 92: 486-492

Gutheil JC, Campbell TN, Pierce PR, Watkins JD, Huse WD, Bodkin DJ, Cheresh DA (2000) Targeted antiangiogenic therapy for cancer using Vitaxin: a humanized monoclonal antibody to the integrin alphavbeta3. Clin Cancer Res 6: 3056-3061

Holash J, Maisonpierre PC, Compton D, Boland P, Alexander CR, Zagzag D, Yancopoulos GD, Wiegand SJ (1999) Vessel cooption, regression, and growth in tumors mediated by angiopoietins and VEGF. Science 284: $1994-1948$

Hyjek E, Chadburn A, Dias S, Zhu Z, Witte L, Hicklin D, Cesarman E, Knowels D, Rafii S (1999) High grade non-Hodgkin's lymphomas and Hodgkin's disease are associated with increased density of KDR+SMA(-) immature microvessels. Blood 94: 597a

Jaffe ES, Harris NL, Stein H, Vardiman JW (2001) Pathology and Genetics of Tumours of Haemopoietic and Lymphoid Tissues. Lyon: IARC Press

Kakolyris S, Fox SB, Koukourakis M, Giatromanolaki A, Brown N, Leek RD, Taylor M, Leigh IM, Gatter KC, Harris AL (2000) Relationship of vascular maturation in breast cancer blood vessels to vascular density and metastasis, assessed by expression of a novel basement membrane component, LH39. Br I Cancer 82: 844-851

Kakolyris S, Giatromanolaki A, Koukourakis M, Leigh IM, Georgoulias V, Kanavaros P, Sivridis E, Gatter KC, Harris AL (1999) Assessment of vascular maturation in non-small cell lung cancer using a novel basement membrane component, LH39: correlation with p53 and angiogenic factor expression. Cancer Res 59: $5602-5607$

Kini AR, Peterson LC, Kay NE (1998) Evidence for abnormal angiogenesis in the bone marrow of patients with B-cell chronic lymphocytic leukemia. Blood 92: 717a

Miliaras D, Kamas A, Kalekou H (1995) Angiogenesis in invasive breast carcinoma: is it associated with parameters of prognostic significance? Histopathology 26: $165-169$

Naresh KN, Nerurkar AY, Borges AM (2001) Angiogenesis is redundant for tumour growth in lymph node metastases. Histopathology 38: 466-470

Navratil E, Couvelard A, Rey A, Henin D, Scoazec JY (1997) Expression of cell adhesion molecules by microvascular endothelial cells in the cortical and subcortical regions of the normal human brain: an immunohistochemical analysis. Neuropathol Appl Neurobiol 23: 68-80

Passalidou E, Trivella M, Singh N, Ferguson M, Hu J, Cesario A, Granone P, Nicholson AG, Goldstraw P, Ratcliffe C, Tetlow M, Leigh I, Harris AL, Gatter KC, Pezzella F (2002) Vascular phenotype in angiogenic and nonangiogenic lung non-small cell carcinomas. Br J Cancer 86: $244-249$

Pazouki S, Chisholm DM, Adi MM, Carmichael G, Farquharson M, Ogden GR, Schor SL, Schor AM (1997) The association between tumour progression and vascularity in the oral mucosa. J Pathol 183: 39-43

Perez-Atayde AR, Sallan SE, Tedrow U, Connors S, Allred E, Folkman J (1997) Spectrum of tumor angiogenesis in the bone marrow of children with acute lymphoblastic leukemia. Am J Pathol 150: 815-821

Pezzella F, Manzotti M, Di Bacco A, Viale G, Nicholson AG, Price R, Ratcliffe C, Pastorino U, Gatter KC, Altman DG, Harris AL, Pilotti S, Veronesi U (2000) Evidence for novel non-angiogenic pathway in breast- cancer metastasis. Breast Cancer Progression Working Party. Lancet 355: $1787-1788$

Pruneri G, Bertolini F, Soligo D, Carboni N, Cortelezzi A, Ferrucci PF, Buffa R, Lambertenghi-Deliliers G, Pezzella F (1999) Angiogenesis in myelodysplastic syndromes. Br J Cancer 81: 1398-1401

Rabb H, Barroso-Vicens E, Adams R, Pow-Sang J, Ramirez G (1996) Alpha$\mathrm{V} /$ beta- 3 and alpha-V/beta-5 integrin distribution in neoplastic kidney. Am J Nephrol 16: $402-408$

Raza A, Lisak L, Andrews C, Little L, Muzammil M, Alvi S, Mazzoran L, Zorat F, Akber A, Ekbal M, Razvi S, Venugopal P (1999) Thalidomide produces transfusion independence in patients with long-standing refractory anemias. Blood 94: 661a

Ribatti D, Vacca A, Nico B, Fanelli M, Roncali L, Dammacco F (1996) Angiogenesis spectrum in the stroma of B-cell non-Hodgkin's lymphomas. An immunohistochemical and ultrastructural study. Eur J Haematol 56: $45-53$

Ribatti D, Vacca A, Nico B, Quondamatteo F, Ria R, Minischetti M, Marzullo A, Herken R, Roncali L, Dammacco F (1999) Bone marrow angiogenesis and mast cell density increase simultaneously with progression of human multiple myeloma. Br J Cancer 79: 451 - 455

Ridell B, Norrby K (2001) Intratumoral microvascular density in malignant lymphomas of B-cell origin. Apmis 109: 66-72

Shami PJ, Hussong JW, Rodgers GM (1998) Evidence of increased angiogenesis inthe bone marrow of patients with acute non-lymphocytic leukemia. Blood 92: 512a

Skobe M, Hawighorst T, Jackson DG, Prevo R, Janes L, Velasco P, Riccardi L, Alitalo K, Claffey K, Detmar M (2001) Induction of tumor lymphangiogenesis by VEGF-C promotes breast cancer metastasis. Nat Med 7: $192-198$

Stewart M, Talks K, Turley H, Pezzella F, Harris A, Gatter K (2002) Expression of angiogenic factors and hypoxia inducible factors Hif-1, Hif-1 and CA IX in non-Hodgkin's lymphoma. Histopathology 40: $253-260$

Tang DG, Diglio CA, Honn KV (1994) Activation of microvascular endothelium by eicosanoid 12(S)- hydroxyeicosatetraenoic acid leads to enhanced tumor cell adhesion via up-regulation of surface expression of alpha v beta 3 integrin: a posttranscriptional, protein kinase $\mathrm{C}$ - and cytoskeleton-dependent process. Cancer Res 54: 1119-1129

Turley H, Scott PA, Watts VM, Bicknell R, Harris AL, Gatter KC (1998) Expression of VEGF in routinely fixed material using a new monoclonal antibody VG1. J Pathol 186: $313-318$

Vacca A, Ribatti D, Presta M, Minischetti M, Iurlaro M, Ria R, Albini A, Bussolino F, Dammacco F (1999a) Bone marrow neovascularization, plasma cell angiogenic potential, and matrix metalloproteinase-2 secretion parallel progression of human multiple myeloma. Blood 93: $3064-3073$

Vacca A, Ribatti D, Roncali L, Ranieri G, Serio G, Silvestris F, Dammacco F (1994) Bone marrow angiogenesis and progression in multiple myeloma. Br J Haematol 87: 503-508

Vacca A, Ribatti D, Ruco L, Giacchetta F, Nico B, Quondamatteo F, Ria R, Iurlaro M, Dammacco F (1999b) Angiogenesis extent and macrophage density increase simultaneously with pathological progression in B-cell non-Hodgkin's lymphomas. Br J Cancer 79: 965-970

Veiga JP, Alfonso H, Sallan SE, Nadler LM, Cardoso AA (1998) Acute lymphoblastic leukaemia cells and their bone marrow stroma collaborate to induce endothelial cell proliferation thereby promoting leukemia cell survival. Blood 92: 511a

Vermeulen PB, Gasparini G, Fox SB, Toi M, Martin L, McCulloch P, Pezzella F, Viale G, Weidner N, Harris AL, Dirix LY (1996) Quantification of angiogenesis in solid human tumours: an international consensus on the methodology and criteria of evaluation. Eur J Cancer 32A: 24742484

Vermeulen PB, Verhoeven D, Fierens H, Hubens G, Goovaerts G, Van Marck E, De Bruijn EA, Van Oosterom AT, Dirix LY (1995) Microvessel quantification in primary colorectal carcinoma: an immunohistochemical study. $\mathrm{Br}$ I Cancer 71: $340-343$

Weidner N (1995) Intratumor microvessel density as a prognostic factor in cancer. Am J Pathol 147: 9-19 